\title{
Pd(II) and Zn(II) Based Complexes with Schiff Base Ligands: Synthesis, Characterization, Luminescence, and Antibacterial and Catalytic Activities
}

\author{
Zhi-Qiang Feng, Xiao-Li Yang, and Yuan-Feng Ye \\ School of Material Engineering, Jinling Institute of Technology, Nanjing 211169, China \\ Correspondence should be addressed to Zhi-Qiang Feng; fzq@jit.edu.cn
}

Received 13 August 2013; Accepted 8 September 2013

Academic Editors: T. I. Gerber and S. F. Lush

Copyright (c) 2013 Zhi-Qiang Feng et al. This is an open access article distributed under the Creative Commons Attribution License, which permits unrestricted use, distribution, and reproduction in any medium, provided the original work is properly cited.

\begin{abstract}
Two new metal complexes involving Schiff base ligands, namely, $\left[\mathrm{Pd}(\mathrm{L} 1)_{2}\right]$ (1) and $\left[\mathrm{Zn}(\mathrm{L} 2)_{2}\right]$ (2), [HL1: 2,4-dibromo-6-((E)(mesitylimino)methyl)phenol and HL2: 2-((E)-(2,6-diisopropylphenylimino)methyl)-4,6-dibromophenol], have been solvothermally synthesized and characterized by elemental analysis, IR-spectroscopy, thermogravimetric analysis, powder X-ray diffraction, and single-crystal X-ray diffraction. Both $\mathbf{1}$ and $\mathbf{2}$ are mononuclear cyclometalated complexes with square planar and tetrahedral coordination geometry, respectively. 1 and 2 display photoluminescence in the solid state at $298 \mathrm{~K}$ (fluorescence lifetimes $\tau=5.521 \mu \mathrm{s}$ at $508 \mathrm{~nm}$ for $\mathbf{1} ; \tau=3.697 \mu \mathrm{s}$ at $506 \mathrm{~nm}$ for 2 ). These Schiff base ligands and their metal complexes have been screened for antibacterial activity against several bacteria strains, and the results are compared with the activity of penicillin. Moreover, the Suzuki reaction of 4-bromoanisole with phenylboronic acid by $\mathbf{1}$ has also been studied.
\end{abstract}

\section{Introduction}

It is wellknown that Schiff bases are important compounds because of their wide range of biological activities [1] and as being ligands in conjunction with transition metals. These transition metals based compounds display diverse structural features and in some instances exhibit interesting reactivities, bacteriostasis, and photoluminescence [2-6]. Compared to platinum(II) complexes involving Schiff base ligands, whose applications as luminescent sensors are of considerable interest in inorganic photochemistry $[7,8]$, relatively scant attention has been focused upon the luminescent characteristics of palladium(II) complexes [9]. Meanwhile, the palladium catalyzed formation of biaryls from aryl halides with arylboronic acids (the Suzuki reaction) has become a mainstay of modern synthetic organic chemistry for the formation of carbon-carbon bonds [10, 11]. Moreover, $\mathrm{Zn}$ (II) complexes bearing salicylaldiminato ligands have been employed as blue, greenish-white, and red emitters in organic optoelectronics with better stability and efficiency $[12,13]$. In those zinc(II) complexes, the salicylaldiminato ligands are mainly salen ligands with two $\mathrm{N}$ and two $\mathrm{O}$ donor atoms. However, reports on the luminescent properties of bis(salicylaldiminato) zinc(II) complexes are still limited. On the basis of the above considerations, we here report the synthesis, characterization, luminescence, and antibacterial and catalytic activities of two new transition metal complexes based on Schiff base ligands.

\section{Experimental}

2.1. Materials and Methods. All chemicals were commercially available and used as received without further purification.

2.2. Physical Measurements. Elemental analyses for $\mathrm{C}, \mathrm{H}$, and $\mathrm{N}$ were carried out using a Vario EL III Elemental Analyzer. Infrared spectra were recorded $\left(4000-400 \mathrm{~cm}^{-1}\right)$ as $\mathrm{KBr}$ disks on a Shimadzu IR-440 spectrometer. Thermogravimetric analyses (TGA) were performed on an automatic simultaneous thermal analyzer (DTG-60, Shimadzu) under a flow of $\mathrm{N}_{2}$ at a heating rate of $10^{\circ} \mathrm{C} / \mathrm{min}$ between ambient temperature and $800^{\circ} \mathrm{C}$. Powder XRD investigations were carried out on a Bruker AXS D8-Advanced diffractometer at $40 \mathrm{kV}$ 
<smiles>Cc1cc(C)c(/N=C/c2cc(Br)cc(Br)c2O)c(C)c1</smiles>

HL-1<smiles>CC(C)c1cccc(C(C)C)c1/N=C/c1cc(Br)cc(Br)c1O</smiles>

HL-2
Scheme 1: The molecular structures of HL1 and HL2.

and $40 \mathrm{~mA}$ with $\mathrm{Cu}-\mathrm{K} \alpha(\lambda=1.5406 \AA)$ radiation. Luminescence spectra and lifetimes for crystalline samples were recorded at room temperature on an Edinburgh FLS920 phosphorimeter. Nuclear Magnetic Resonance spectra were recorded on a Bruker Avance $400 \mathrm{MHz}$ spectrometer. ${ }^{1} \mathrm{H}$ NMR chemical shifts are reported in ppm from tetramethylsilane with the solvent resonance as the internal standard $\left(\mathrm{CDCl}_{3}, \delta=7.26\right)$. Data are reported as follows: chemical shift $(\delta \mathrm{ppm})$, multiplicity $(\mathrm{s}=$ singlet, $\mathrm{d}=$ doublet, $\mathrm{t}=$ triplet, and $\mathrm{m}=$ multiplet $)$, coupling constants $(\mathrm{Hz})$, integration, and assignment. ${ }^{13} \mathrm{C}$-NMR spectra were collected on a $100 \mathrm{MHz}$ spectrometer with complete proton decoupling. Chemical shifts were reported in ppm from the tetramethylsilane (TMS) with the solvent resonance as internal standard $\left(\mathrm{CDCl}_{3}, \delta=77.23\right)$. Melting points (uncorrected) were measured with a Mel-Temp apparatus.

\section{Solvothermal Synthesis}

3.1. Preparation of $\mathbf{H L 1}$. The preparation of HLl was carried out according to the reported procedures [14]. Yield $6.013 \mathrm{~g}(72 \%) .{ }^{1} \mathrm{H}$ NMR $\left(400 \mathrm{MHz}, \mathrm{CDCl}_{3}\right) \delta: 14.32$ (s, $1 \mathrm{H}$, $\mathrm{OH}), 8.20(\mathrm{~s}, 1 \mathrm{H}, \mathrm{CHN}), 7.24-7.77(\mathrm{~m}, 4 \mathrm{H}, \mathrm{Ar}-\mathrm{H}), 2.22(\mathrm{~d}$, $\left.J=51.2 \mathrm{~Hz}, 9 \mathrm{H}, \mathrm{CH}_{3}\right) ;{ }^{13} \mathrm{C}$ NMR $\left(100 \mathrm{MHz}, \mathrm{CDCl}_{3}\right) \delta$ : $164.6,157.9,144.4,138.4,135.7,133.2,129.5,128.7,120.4,112.5$, 110.3, 20.7, 18.3; MP: $90-93^{\circ} \mathrm{C}$. FTIR $\left(\mathrm{KBr}, \mathrm{cm}^{-1}\right)$ : $3462(\mathrm{~s})$, 2920(m), 2891(m), 1628(s), 1560(w), 1490(m), 1449(m), 1374(w), 1295(w), 1266(w), 1224(w), 1201(w), 1198(w), 1155(w), 1134(w), 1125(m), 1034(m), 992(w), 877(m), 849(m), 801(w), 765(w), 724(w), 688(s), 551(w), 485(w), 442(w), as shown in Scheme 1.

3.2. Preparation of $\mathbf{H L 2}$. HL2 was prepared by the same procedure as for HL1 except that 2,4,6-trimethylaniline was replaced by 2,6-diisopropylaniline. Yield $6.11 \mathrm{~g}(71 \%) .{ }^{1} \mathrm{H}$ NMR $\left(400 \mathrm{MHz}, \mathrm{CDCl}_{3}\right) \delta: 14.11(\mathrm{~s}, 1 \mathrm{H}, \mathrm{OH}), 8.21(\mathrm{~s}, 1 \mathrm{H}$, CHN), 7.44-7.79 (m, 5H, Ar-H), $2.93(\mathrm{~d}, J=4.6 \mathrm{~Hz}, 12 \mathrm{H}$, $\left.\mathrm{CH}_{3}\right) ; 1.18\left(\mathrm{~m}, \mathrm{~J}=4.6 \mathrm{~Hz}, 2 \mathrm{H}, \mathrm{CH}\left(\mathrm{CH}_{3}\right)_{2}\right) \cdot{ }^{13} \mathrm{C} \mathrm{NMR}$ $\left(100 \mathrm{MHz}, \mathrm{CDCl}_{3}\right) \delta: 164.9,157.4,144.9,138.9,138.3,133.5$, 126.2, 123.4, 120.2, 112.3, 110.3, 28.2, 23.6; MP: $135-137^{\circ}$ C. FTIR $\left(\mathrm{KBr}, \mathrm{cm}^{-1}\right): 3460(\mathrm{~s}), 2958(\mathrm{~s}), 2915(\mathrm{w}), 1612(\mathrm{vs}), 1442(\mathrm{~s})$, 1385(w), 1350(m), 1319(w), 1295(m), 1214(w), 1157(w), 1114(w), 1087(w), 1034(m), 992(w), 932(m), 859(m), 801(w), 765(w), 724(w), 688(s), 551(w), 512(w), as shown in Scheme 1.

3.3. Preparation of $\left[\mathrm{Pd}(L 1)_{2}\right]$ (1). $\mathrm{Pd}\left(\mathrm{C}_{2} \mathrm{H}_{3} \mathrm{O}_{2}\right)_{2} \quad(0.112 \mathrm{~g}$, $0.5 \mathrm{mmol})$ was dissolved in methanol $(15 \mathrm{~mL})$. HLl $(0.359 \mathrm{~g}$, $1 \mathrm{mmol}$ ) was added, and the mixture was stirred at room temperature for $2 \mathrm{~h}$ under an anhydrous atmosphere. The resulting mixture was filtered under reduced pressure. The collected solid was washed with diethyl ether and dried in air to give yellow crystals that were purified by recrystallization from methylene chloride $(10 \mathrm{~mL})$ and hexane $(10 \mathrm{~mL})$. Yield $0.315 \mathrm{~g}(70 \%)$. Anal. For $\mathrm{C}_{32} \mathrm{H}_{28} \mathrm{Br}_{4} \mathrm{~N}_{2} \mathrm{O}_{2} \mathrm{Pd}$ (\%): Calcd. C 42.7, H 3.1, N 3.1; found C 42.2, H 3.5, N 3.7. FTIR (KBr, $\left.\mathrm{cm}^{-1}\right)$ : 3458(s), 2960(m), 2921(w), 1604(vs), 1580(s), 1508(vs), 1462(s), 1450(m), 1384(w), 1361(w), 1327(w), 1298(w), 1253(w), 1220(w), 1178(w), 1112(m), 1058(w), 1032(w), 929(w), 918(w), 877(m), 815(m), 797(m), 754(s), 703(w), 669(w), 577(w), 505(w) 482(w), 435(w), 413(w).

3.4. Preparation of $\left[\mathrm{Zn}(\mathrm{L} 2)_{2}\right]$ (2). Complex 2 was prepared by the same procedure as $\mathbf{1}$ except that HLI was replaced with HL2. Yield $0.12 \mathrm{~g}(86 \%)$. Anal. For $\mathrm{C}_{32} \mathrm{H}_{28} \mathrm{~N}_{2} \mathrm{O}_{2} \mathrm{Br}_{4} \mathrm{Zn}$ (\%): Calcd. C 44.8, H 3.3, N 3.3; found C 45.3, H 3.2, N 3.0. FTIR (KBr, cm $\left.{ }^{-1}\right)$ : 3465(s), 2975(m), 2916(s), 1603(vs), 1473(s), 1440(s), 1309(m), 1199(m), 1120(w), 1016(w), 997(w), 960(w), 945(w), 844(m), 756(s), 694(s), 623(w), 590(w), 555(m), 498(s), 476(m), 424(w), 401(s).

3.5. Antibacterial Activity Tests. In vitro bacterial activities of the Schiff base ligands and their metal complexes were tested using the paper disc diffusion method. The chosen strains were G(+) S. aureus and B. cereus and Rhizopus and E. coli. The liquid medium containing the bacterial subcultures was autoclaved for $20 \mathrm{~min}$ at $15 \mathrm{lb}$ pressure before inoculation. The bacteria were cultured for $24 \mathrm{~h}$ at $35^{\circ} \mathrm{C}$ in an incubator. Mueller Hinton broth was used for preparing basal media for the bioassay of the organisms. Nutrient agar was poured onto a Petri plate and allowed to solidify. The test compounds were dissolved in DMF and added dropwise to $10 \mathrm{~mm}$ diameter paper discs placed in the center of the agar plates. The plates were then kept at $5^{\circ} \mathrm{C}$ for $1 \mathrm{~h}$ and transferred to an incubator maintained at $35^{\circ} \mathrm{C}$. The width of the growth inhibition zone around the disc was measured after $24 \mathrm{~h}$ of incubation. Four replicates were taken for each treatment. In order to clarify any participating role of DMF in the biological screening, separate control studies were carried out with the solutions of DMF alone, and they showed no activity against any bacterial strains.

3.6. Catalytic Reactions. A mixture of 4-bromotoluene $(1.0 \mathrm{mmol})$, phenylboronic acid $(1.2 \mathrm{mmol})$, organic solvents $(6 \mathrm{~mL})$, bases $(2.0 \mathrm{mmol})$, and $0.5 \mathrm{~mol} \%$ of catalyst was stirred at $80^{\circ} \mathrm{C}$ under air. After the reaction, the catalyst was separated by filtration. The filtrate was dried over $\mathrm{Na}_{2} \mathrm{SO}_{4}$ and filtered. The products were quantified by GC-MS analysis (Shimadzu GCMS-QP5050A equipped with a $0.25 \mathrm{~mm} \times$ $30 \mathrm{~m}$ DB-WAX capillary column). The typical GC-MS analysis program was as follows: set initial column temperature 
TABLE 1: Crystal and refinement data.

\begin{tabular}{lcc}
\hline Compounds & 1 & 2 \\
Empirical formula & $\mathrm{C}_{32} \mathrm{H}_{28} \mathrm{Br}_{4} \mathrm{~N}_{2} \mathrm{O}_{2} \mathrm{Pd}$ & $\mathrm{C}_{38} \mathrm{H}_{40} \mathrm{Br}_{4} \mathrm{~N}_{2} \mathrm{O}_{2} \mathrm{Zn}$ \\
Formula weight & 898.60 & 941.73 \\
Temperature $(\mathrm{K})$ & $296(2)$ & $296(2)$ \\
Crystal system & Monoclinic & Monoclinic \\
Space group & $P 2_{1} / n$ & $C 2 / c$ \\
$a(\AA)$ & $10.9718(16)$ & $20.161(3)$ \\
$b(\AA)$ & $11.8932(17)$ & $17.970(3)$ \\
$c(\AA)$ & $12.2321(18)$ & $23.087(3)$ \\
$\beta\left(^{\circ}\right)$ & $92.733(3)$ & $111.306(3)$ \\
$V\left(\AA^{3}\right)$ & $1594.3(4)$ & $7793(2)$ \\
$Z, D\left(\right.$ Mg.m $\left.{ }^{3}\right)$ & $2,1.872$ & $8,1.605$ \\
Limiting indices & $-13 \leq \mathrm{h} \leq 12,-14 \leq \mathrm{k}$ & $-24 \leq \mathrm{h} \leq 24,-21 \leq$ \\
Reflections & $\leq 13,-14 \leq 1 \leq 14$ & $\mathrm{k} \leq 17,-27 \leq 1 \leq 26$ \\
collected/unique & $8635 / 2853$ & $21523 / 7002$ \\
$F(000)$ & 872 & 3744 \\
$\theta\left(^{\circ}\right)$ & $2.39-25.20$ & $1.57-25.20$ \\
Goodness-of-fit on & 1.098 & 0.984 \\
$F^{2}$ & $R_{1}=0.0345$ & $R_{1}=0.0459$ \\
$R(I>2 \sigma)$ & $w R_{2}=0.1068$ & $w R_{2}=0.1267$ \\
$R($ all data $)$ & $R_{1}=0.0542$ & $R_{1}=0.0831$ \\
Largest diff. peak & $w R_{2}=0.1345$ & $w R_{2}=0.1565$ \\
and hole $\left(\AA^{-3}\right)$ & $0.936,-0.761$ & 1.047 and -1.072 \\
$R=\sum\left(\left\|F_{o}|-| F_{c}\right\|\right) / \sum\left|F_{o}\right|$. & & \\
$w R=\left[\sum w\left(F_{o}{ }^{2}-F_{c}{ }^{2}\right)^{2} / \sum w\left(F_{o}\right)^{2}\right]^{1 / 2}$. & \\
& &
\end{tabular}

as $100^{\circ} \mathrm{C}$, hold $2 \mathrm{~min}$, ramp temperature to $280^{\circ} \mathrm{C}$ at $15^{\circ} \mathrm{C} / \mathrm{min}$, and hold for $5 \mathrm{~min}$.

3.7. X-Ray Crystallography. Single crystal X-ray diffraction analyses of complexes 1-2 were performed on a Bruker Apex II CCD diffractometer operating at $50 \mathrm{kV}$ and $30 \mathrm{~mA}$ using MoK $\alpha$ radiation $(\lambda=0.71073 \AA)$. Data collection and reduction were performed using the APEX II software [15]. Multiscan absorption corrections were applied for all the data sets using SADABS, as included in the APEX II program [15]. The structure was solved by direct methods and refined by least squares on $\mathrm{F}^{2}$ using the SHELXTL program package [16]. All nonhydrogen atoms were refined with anisotropic displacement parameters. Hydrogen atoms attached to carbon and oxygen were placed in geometrically idealized positions and refined using a riding model. Crystallographic data are listed in Table 1. Selected bond lengths and angles and $\mathrm{H}$ bonding parameters for compound 2 are given in Tables 2 and 3 , respectively.

\section{Results and Discussion}

4.1. Structure of $\mathbf{1}$. Complex $\mathbf{1}$ crystallizes in the monoclinic space group $P 2_{1} / n$ and contains one $\mathrm{Pd}(\mathrm{II})$ ion and two
TABLE 2: Selected bond length and angles of 1-2.

\begin{tabular}{lccc}
\hline Compound 1 & & & \\
\hline Pd1-N1 & $2.026(4)$ & Pd1-O1 & $1.970(3)$ \\
O1-Pd1-O1 $^{i}$ & $180.000(1)$ & O1-Pd1-N1 & $93.06(16)$ \\
O1 $^{i}-\mathrm{Pd} 1-N 1^{i}$ & $86.94(16)$ & O1 $^{i}-\mathrm{Pd} 1-\mathrm{N} 1$ & $93.06(16)$ \\
O1-Pd1-N1 & $86.94(16)$ & $\mathrm{N1}^{i}-\mathrm{Pd} 1-\mathrm{N} 1$ & 180.000 \\
\hline Compound 2 & & & \\
\hline Zn1-N1 & $2.020(4)$ & Zn1-N2 & $2.027(4)$ \\
Zn1-O1 & $1.933(3)$ & Zn1-O2 & $1.941(4)$ \\
O2-Zn1-O1 & $112.32(16)$ & O2-Zn1-N2 & $93.82(16)$ \\
O1-Zn1-N2 & $114.07(16)$ & O2-Zn1-N1 & $116.48(17)$ \\
O1-Zn1-N1 & $94.47(16)$ & N1-Zn1-N2 & $126.72(18)$ \\
\hline
\end{tabular}

Symmetry code $-i: 2-x, 1-y, 2-z$.

TABLE 3: Hydrogen bond geometries for $2\left(\AA,^{\circ}\right)$.

\begin{tabular}{lcccc}
\hline $\mathrm{D}-\mathrm{H} \cdots \mathrm{A}$ & $d(\mathrm{D}-\mathrm{H})$ & $d(\mathrm{H} \cdots \mathrm{A})$ & $d(\mathrm{D} \cdots \mathrm{A})$ & $\angle \mathrm{D}-\mathrm{H} \cdots \mathrm{A}$ \\
\hline $\mathrm{C} 14-\mathrm{H} 14 \cdots \mathrm{N} 1$ & 0.98 & 2.50 & $2.974(1)$ & 110 \\
$\mathrm{C} 17-\mathrm{H} 17 \cdots \mathrm{N} 1$ & 0.98 & 2.38 & $2.872(2)$ & 110 \\
$\mathrm{C} 33-\mathrm{H} 33 \cdots \mathrm{N} 2$ & 0.98 & 2.47 & $2.935(2)$ & 109 \\
$\mathrm{C} 36-\mathrm{H} 36 \cdots \mathrm{N} 2$ & 0.98 & 2.44 & $2.928(8)$ & 110 \\
\hline
\end{tabular}

crystallographically independent L1 ligands, as shown in Figure 1. In this complex, each Schiff base ligand (L1) is bonded to the $\mathrm{Pd}(\mathrm{II})$ center through nitrogen atom and oxygen atom, providing two equivalent six-membered $\mathrm{N}-$ $\mathrm{Pd}-\mathrm{O}-\mathrm{C}$-chelate rings. The geometry at the $\mathrm{Pd}(\mathrm{II})$ center in $\mathbf{1}$ is square planar, with the two cyclometalated ligands in a trans arrangement. The $\mathrm{Pd}-\mathrm{O}$ and $\mathrm{Pd}-\mathrm{N}$ distances are $1.969(3)$ and $2.026(4) \AA$, similar to those seen in related complexes $[4,17]$. In the six-membered chelate rings, the six atoms (Pd1, O1, C1, C6, C7, N1) are essentially planar. The planes of the two phenyl rings are inclined by 4.12(2) and $87.87(3)^{\circ}$ to the $\mathrm{PdN}_{2} \mathrm{O}_{2}$ coordination plane, respectively. The bite angle $\left[\mathrm{N} 1-\mathrm{Pd} 1-\mathrm{O} 1=93.04(4)^{\circ}\right]$ is in good agreement with those found in a structurally related mononuclear complex with salicylaldiminato ligands as bridging ligands $[12,13]$.

4.2. Structure of 2. X-ray crystallography shows that complex 2 crystallizes in the monoclinic space group $C 2 / c$ and adopts a distorted tetrahedral geometry with the $\mathrm{Zn}{ }^{\mathrm{II}}$ center chelated by two bidentate $\mathbf{L} 2$ ligands through the phenolate oxygen atom and imine nitrogen atom (Figures 2(a) and 2(b)). The $\mathrm{O}-\mathrm{Zn}-\mathrm{O}$ angle in $2\left(111.32(16)^{\circ}\right)$ is close to those values $\left(105-112.5^{\circ}\right)$ in the similar bissalicylaldiminato zinc complexes $\left(\mathrm{NR}^{2} \mathrm{C}_{7} \mathrm{H}_{5-x}\left(\mathrm{R}^{1}\right)_{x} \mathrm{O}\right)_{2} \mathrm{Zn}\left[x=1\right.$ or $2 ; \mathrm{R}^{1}=$ $\mathrm{Me},{ }^{t} \mathrm{Bu}, \mathrm{Cl}$, OMe; $\mathrm{R}^{2}=2,6{ }^{i} \operatorname{Pr}_{2} \mathrm{C}_{6} \mathrm{H}_{3}$ ] [18], while the $\mathrm{N}-$ $\mathrm{Zn}-\mathrm{N}$ angle in $2\left(126.72(18)^{\circ}\right)$ is also close to those in the latter complexes $\left(122.9-128.9^{\circ}\right)$. The two dihedral angles between the phenyl rings ( $\mathrm{C} 8-\mathrm{C} 13$ and $\mathrm{C} 27-\mathrm{C} 32)$ and the sixmembered chelating ring (O1-Zn1-N1-C7-C1-C2) are 84.90 and $86.35^{\circ}$, respectively. The two six-membered chelating rings are nearly planar with the zinc atoms lying 0.513 and $0.310 \AA$ out of the plane, and they are closely perpendicular to each other with the dihedral angle being $86.50^{\circ}$. 


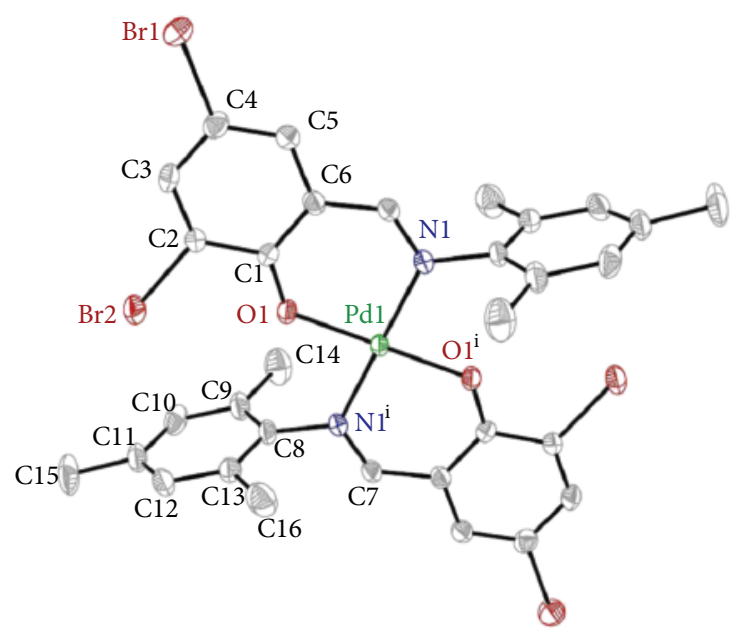

FIGURE 1: The molecular structure of compound 1 with numbering scheme (30\% probability ellipsoids). All $\mathrm{H}$ atoms are omitted for clarity. Symmetry code: (i) $2-x, 1-y, 2-z$.

The imino $\mathrm{C}=\mathrm{N}$ bonds in 2 retain their double bond character, being 1.298(6) $\AA(\mathrm{C} 26=\mathrm{N} 2)$ and $1.256(6) \AA(\mathrm{C} 7=\mathrm{N} 1)$ in length. The mononuclear molecules are connected into a 1D infinite chain through intermolecular $\pi \cdots \pi$ and $\mathrm{C} 34-\mathrm{H} 34 \mathrm{~A} \cdots \pi$ stacking interactions between benzene rings (Cg1) of L2 ligands, with a centroid-to-centroid distance of 3.786(7) $\AA$ (Figure 3) ( $\mathrm{Cg} 1$ is the centroid of the $\mathrm{Cl}-\mathrm{C} 6$ ring). Intramolecular $\mathrm{C} 15-\mathrm{H} 15 \mathrm{~B} \cdots \pi$ and $\mathrm{C} 35-\mathrm{H} 35 \mathrm{~A} \cdots \pi$ stacking interactions further stabilize the $1 \mathrm{D}$ chain. The $\mathrm{H}$-tocentroid distances of $\mathrm{H} 34 \mathrm{~A} \cdots \mathrm{Cg} 2^{i}=2.93(2) \AA, \mathrm{H} 15 \mathrm{~B} \cdots \mathrm{Cg} 3$ $=2.69(3) \AA$, and $\mathrm{H} 35 \mathrm{~A} \cdots \mathrm{Cg} 4=2.93(7) \AA,[\mathrm{Cg} 2, \mathrm{Cg} 3$, and $\mathrm{Cg} 4$ are the centroid of the $\mathrm{C} 20-\mathrm{C} 25, \mathrm{C} 27-\mathrm{C} 32$, and C8C13 rings, respectively, symmetry code: $i=-x, y, 0.5-z]$. Moreover, weak intramolecular $\mathrm{C}-\mathrm{H} \cdots \mathrm{N}$ hydrogen bonds are also observed (Table 3).

4.3. Powder X-Ray Diffraction Analysis. In order to check the purity of complexes 1-2, bulk samples were measured by $\mathrm{X}$-ray powder diffraction at room temperature, as shown in Figure 4. Although the experimental patterns have a few unindexed diffraction lines and some are lightly broadened in comparison with those simulated from the single-crystal data using Mercury, it still can be well considered that the bulk synthesized materials and the crystals used for diffraction are homogeneous.

4.4. Infrared Spectra. FT-IR spectra of HL1, HL2, 1, and 2 were recorded as $\mathrm{KBr}$ pellets (see Figure S1 in Supplementary Material available online at http://dx.doi.org/ $10.1155 / 2013 / 956840)$. In the IR spectrum, moderate bands at 2920 and $2891 \mathrm{~cm}^{-1}$ for HL1, 2958 and $2915 \mathrm{~cm}^{-1}$ for HL2, 2960 and $2921 \mathrm{~cm}^{-1}$ for 1, and 2975 and $2916 \mathrm{~cm}^{-1}$ for $\mathbf{2}$ are associated with the methyl $\left(-\mathrm{CH}_{3}\right)$ or methine (-CH-) stretching vibrations. The features at $1628 \mathrm{~cm}^{-1}$ for HL1, $1612 \mathrm{~cm}^{-1}$ for HL2, $1604 \mathrm{~cm}^{-1}$ for 1 , and $1603 \mathrm{~cm}^{-1}$ for 2 may be assigned to the $-\mathrm{CH}=\mathrm{N}-$ stretching vibrations.
The absorption peaks of $-\mathrm{CH}=\mathrm{N}$ - group in $\mathbf{1}$ and $\mathbf{2}$ are clearly blue shifted against the related ligands, perhaps due to the conjugative effect between metal ions and ligands.

4.5. Thermogravimetric Analysis of 1-2. The TG and DTA curves of 1-2 are shown in Figure 5. Both structures show good thermal stability as no clean weight-loss step occurs below $280^{\circ} \mathrm{C}$ for $\mathbf{1}$ and $320^{\circ} \mathrm{C}$ for 2 . The DTA trace of $\mathbf{2}$ shows superior endotherm to $\mathbf{1}$ indicating that $\mathbf{2}$ has better thermal stability than 1 . The weight-loss step above $280^{\circ} \mathrm{C}$ and $320^{\circ} \mathrm{C}$ corresponds to decomposition of the framework structures. Finally, $\mathbf{1}$ and $\mathbf{2}$ were completely degraded into $\mathrm{PdO}$ and $\mathrm{ZnO}$, respectively, with total loss of $84.1 \mathrm{wt} \%$ (calcd. $86.4 \mathrm{wt} \%$ ) for 1 and $89.7 \mathrm{wt} \%$ (calcd. $91.3 \mathrm{wt} \%$ ) for 2.

4.6. Luminescent Properties. As part of a continuing program dedicated to luminescent transition systems, the spectroscopic behavior of complexes 1-2 is presented. The solidstate emission luminescence spectra of $\mathbf{1}$ at room temperature upon excitation at $340 \mathrm{~nm}$ are shown in Figure 6. The emission spectrum shows two bands at $\lambda_{\max }=508$ and $766 \mathrm{~nm}$, respectively. The solid-state excitation spectra for 1 reveal the presence of low-energy ligand-field states in the 300-400 $\mathrm{nm}$ spectral region. The high-energy structured band of $\mathbf{1}$ is assigned to a transition to ${ }^{3}$ IL excited state [19]. Complex 2 emits strong blue light in the solid state at room temperature with maximal emission wavelength at $506 \mathrm{~nm}$ (excitation wavelength $354 \mathrm{~nm}$, Figure 6).

The coordinated zinc atom plays a dual role in the luminescence of $\mathbf{2}$ as pointed out in the literature for coordination complexes [20]. First, the formation of covalent bonds between the $\mathrm{Zn}$ and $\mathrm{O}$ atoms via $\pi$-donation of a lone-pair electrons on the $\mathrm{O}$ atom to the $\mathrm{Zn}$ atom changes the emission energy due to the lowering of the energy gap between $\pi^{*}$ and $\pi$. Second, the coordination of the ligands with the $\mathrm{Zn}$ atom increases the rigidity of the ligands, which can diminish the loss of energy via vibrational motions and increase the emission efficiency. Compared to the free ligands, the emission maxiumu of $\mathbf{1 - 2}$ is obviously red-shifted (see Figure S2) in the solid state, which may be assigned as metal-to-ligand charge transfer [21]. The luminescence lifetimes of solids 1-2 using an Edinburgh FLS S920 phosphorimeter with a $450 \mathrm{~W}$ xenon lamp as excitation source show lifetimes for 1 of $\tau=5.521 \mu \mathrm{s}$ at $508 \mathrm{~nm}$ and for 2 of $\tau=4.023 \mu$ s at $506 \mathrm{~nm}$ (Figure 7). It should be noted that complexes $\mathbf{1}$ and $\mathbf{2}$ possess longer fluorescence lifetime than other palladium and zinc complexes involving Schiff bases $[2,22]$ and so could be used for lightemitting luminescent materials.

4.7. Biological Activity Tests. The susceptibility of certain strains of bacterium towards the ligands HL1-HL2 and their metal complexes 1-2 was judged by measuring the size of their bactericidal diameters (vide supra). The results are given in Table 4. The effect against Staphylococcus aureus of ligands and complexes was found to be close to that of sodium penicillinate. All of the ligands and complexes showed inhibition diameters larger than sodium penicillinate against Bacillus cereus. Compared to HL1-HL2 and 1-2 which show 


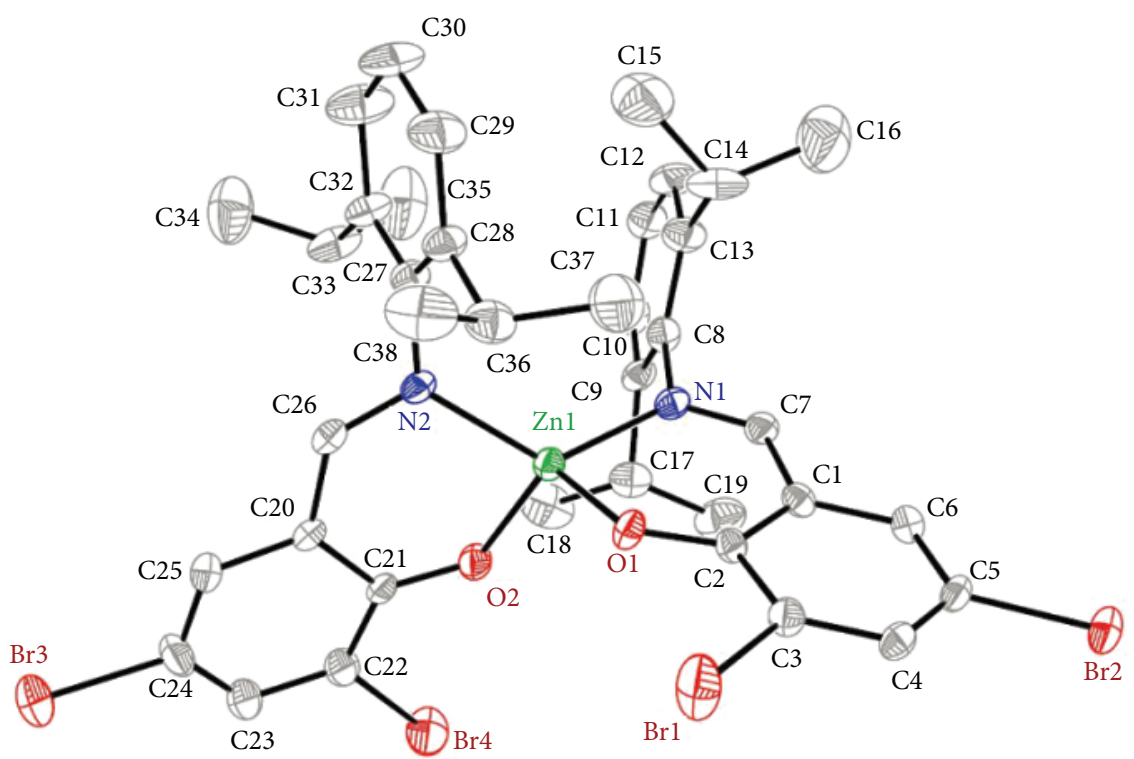

(a)

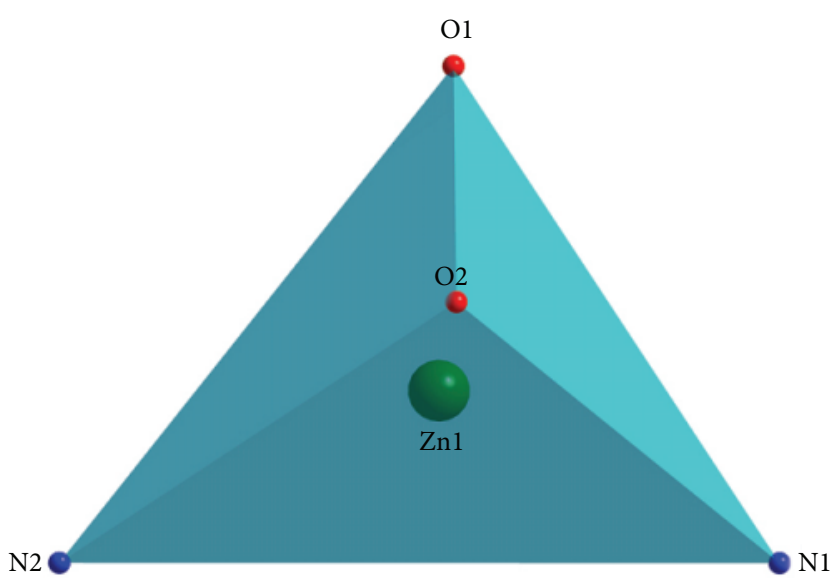

(b)

Figure 2: (a) The molecular structure of 2 with numbering scheme (30\% probability ellipsoids). All $\mathrm{H}$ atoms are omitted for clarity; (b) tetrahedral geometry surrounding the $\mathrm{Zn}$ (II) atom of $\mathbf{2}$.

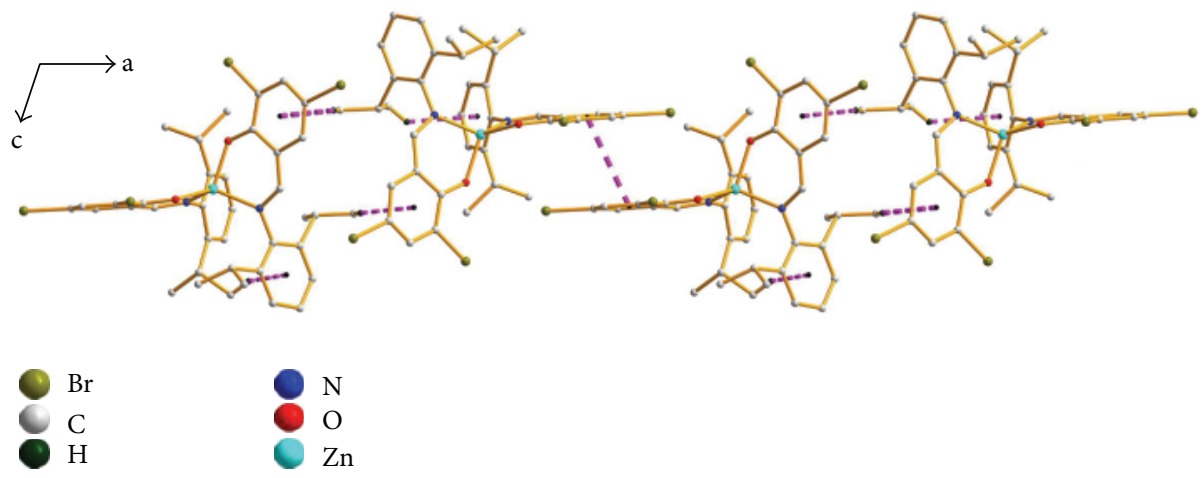

FIGURE 3: View of an infinite chain of 2 formed by intermolecular $\pi \cdots \pi$ and $\mathrm{C}-\mathrm{H} \cdots \pi$ stacking interactions with pink dashes. 

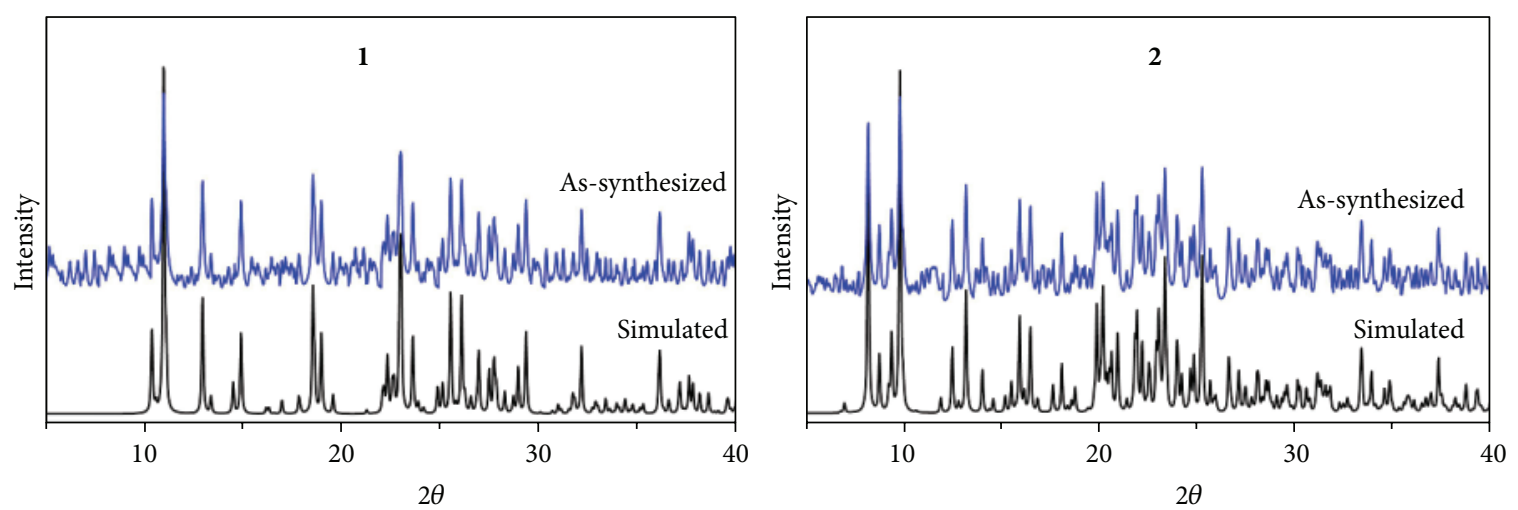

FIGURE 4: PXRD patterns in complexes 1-2.
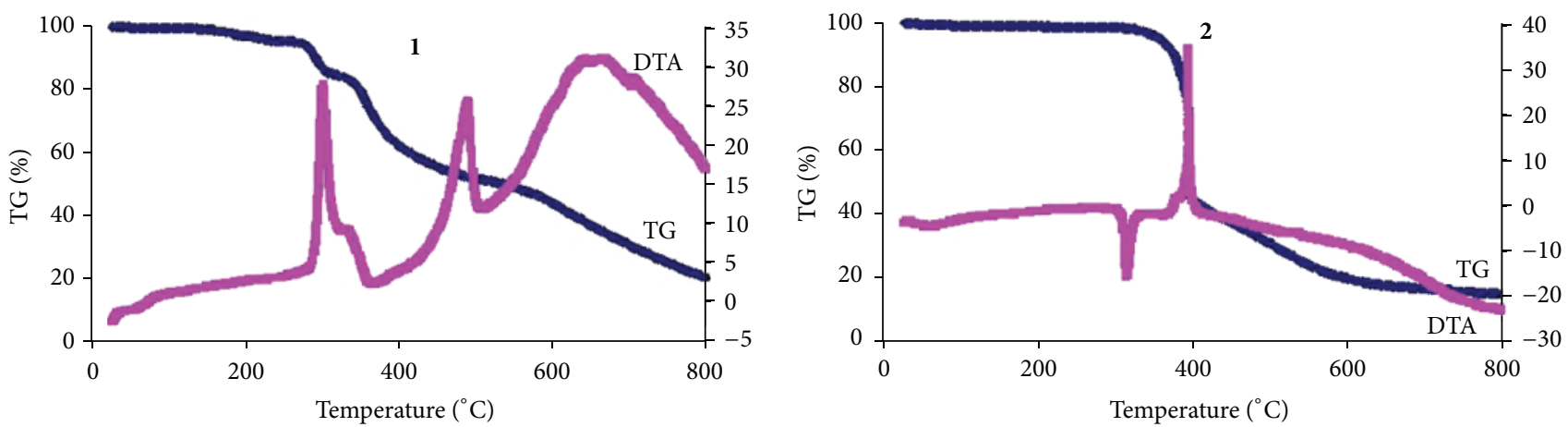

FIgURE 5: Thermogravimetric curves (TG and DTA) for complexes 1-2.
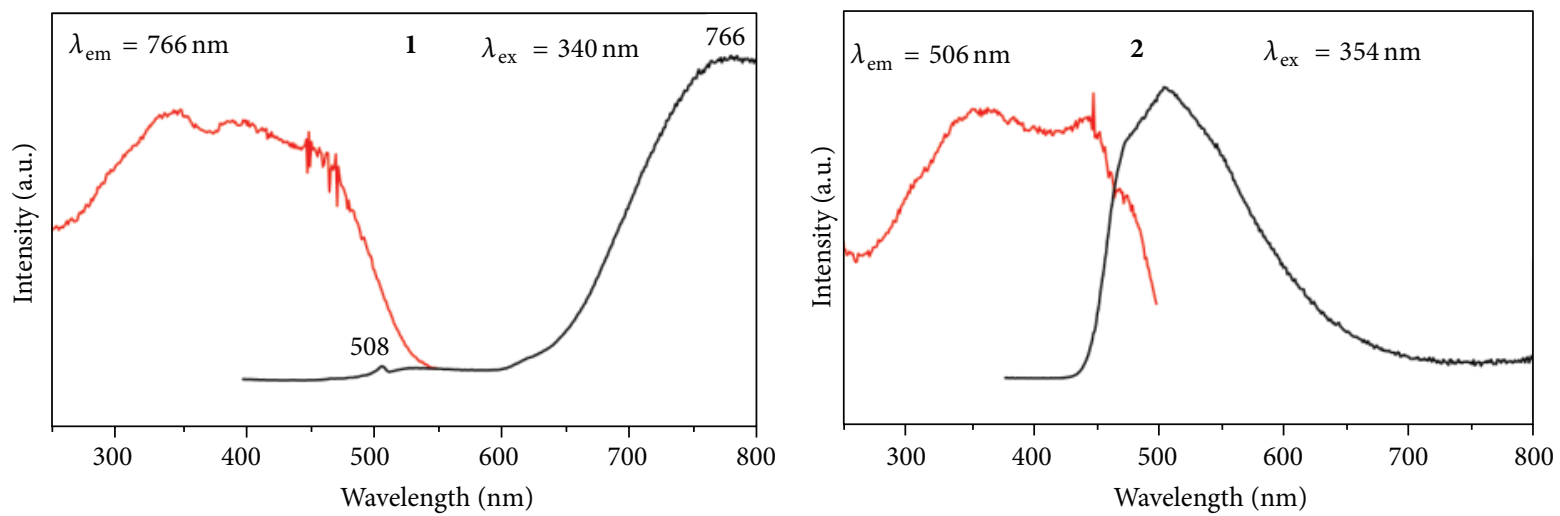

FIgURE 6: Solid-state excitation and emission spectra of $\mathbf{1}$ and $\mathbf{2}$ at room temperature.

good activities, the penicillin is ineffective against Escherichia coli. However, similar to sodium penicillinate, the four tested samples showed no appreciable activity. Moreover, we found that the complexes were more effective than the ligands. It is possible that the ligand may be activated by the metal ion [23]. El-Sherif reported a series of palladium complexes that show antibacterial activities against $S$. pyogenes and E. coli bacteria at different concentrations $1,2.5$, and $5 \mathrm{mg} / \mathrm{mL}$ in DMSO in which the activities were smaller in the complexes than in ligands [24]. Also the results obtained for $\mathbf{1}$ and HL show better antibacterial activities compared to the platinum(II) and palladium(II) complexes based on Schiff bases [20].
4.8. Suzuki Reaction Catalysis of $\mathbf{1}$. Pd(II) based complexes are well known for their catalytic activities [2,5]. The Suzuki reaction of 4-bromoanisole with phenylboronic acid by $\mathbf{1}$ is reported here. The results reveal that the base and solvent for the Suzuki reaction greatly influence catalytic activity (Table 5). The reaction temperature has lower effect on the catalytic activity of $\mathbf{1}$. Among six different organic solvents, $\mathrm{DMF}$ is found to the best solvent for this catalytic system. In other organic solvents, for example, ethanol, ethanol/water $(2: 2)$, ethylene glycol, acetonitrile, and toluene, relatively low yields of coupling products were obtained. Among five different bases investigated for these reactions, NaOAc 
TABLE 4: Antibacterial activities of the ligands and complexes.

\begin{tabular}{|c|c|c|c|c|c|}
\hline \multirow{2}{*}{ Entry } & \multirow{2}{*}{$(\mu \mathrm{g} /$ disc $)$} & \multicolumn{4}{|c|}{ Zone of Inhibition (mm) } \\
\hline & & S. aureus & B. cereus & Rhizopus & E. coli \\
\hline \multirow{3}{*}{ HL1 } & 20 & 21 & 18 & 0 & 22 \\
\hline & 10 & 11 & 8 & 0 & 9 \\
\hline & 2 & 0 & 0 & 0 & 0 \\
\hline \multirow{3}{*}{1} & 20 & 24 & 21 & 0 & 27 \\
\hline & 10 & 15 & 11 & 0 & 13 \\
\hline & 2 & 4 & 0 & 0 & 6 \\
\hline \multirow{3}{*}{ HL2 } & 20 & 23 & 22 & 0 & 24 \\
\hline & 10 & 10 & 9 & 0 & 11 \\
\hline & 2 & 0 & 0 & 0 & 0 \\
\hline \multirow{3}{*}{2} & 20 & 26 & 27 & 0 & 29 \\
\hline & 10 & 14 & 13 & 0 & 16 \\
\hline & 2 & 6 & 0 & 0 & 8 \\
\hline \multirow{3}{*}{ Penicillin } & 20 & 36 & 14 & 0 & 0 \\
\hline & 10 & 15 & 0 & 0 & 0 \\
\hline & 2 & 0 & 0 & 0 & 0 \\
\hline \multirow{3}{*}{ DMF } & 20 & - & - & - & - \\
\hline & 10 & - & - & - & - \\
\hline & 2 & - & - & - & - \\
\hline
\end{tabular}
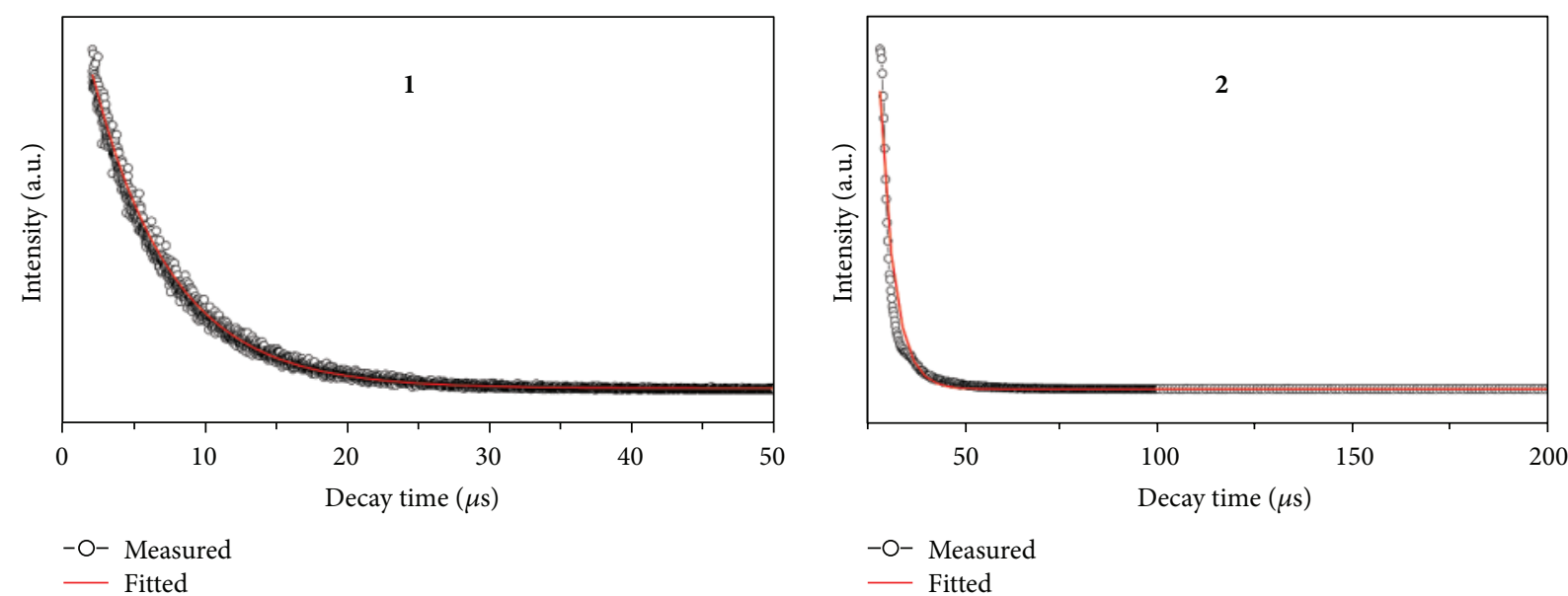

FIGURE 7: Luminescence lifetimes for complexes 1-2 in solid state at room temperature.

was found to be the most effective (Table 5, entry 1); $\mathrm{K}_{2} \mathrm{CO}_{3}, \mathrm{Na}_{2} \mathrm{CO}_{3}, \mathrm{CH}_{3} \mathrm{ONa}$, and $\mathrm{NaOH}$ were substantially less effective. KF failed to promote the reaction (Table 5 , entry 13). Compared with other Pd(II) complexes based on Schiff base ligands, the catalytic activities of the present complexes for the Suzuki reaction proved to be highly effective [25].

\section{Conclusion}

In summary, two new transition metal complexes based on Schiff base ligands have been successfully synthesized under solvothermal conditions. Both 1 and 2 show good thermal stability and exhibit photoluminescence in the solid state at room temperature $(\tau=5.521 \mu$ s at $508 \mathrm{~nm}$ for $1, \tau=3.697 \mu$ s at $506 \mathrm{~nm}$ for 2), suggesting utility as light-emitting luminescent materials. The antibacterial activity tests showed that the ligands and complexes exhibited superior biological activity against Staphylococcus aureus, Bacillus cereus, and Escherichia coli. Moreover, complex 1 displays highly catalytic activities in the Suzuki coupling reaction of 4-bromoanisole with phenylboronic acid, which are also very sensitive to the choice of base and solvent. 
TABLE 5: The effect of base and solvent on complex 1 catalyzed Suzuki reaction of 4-bromoanisole with phenylboronic acid.

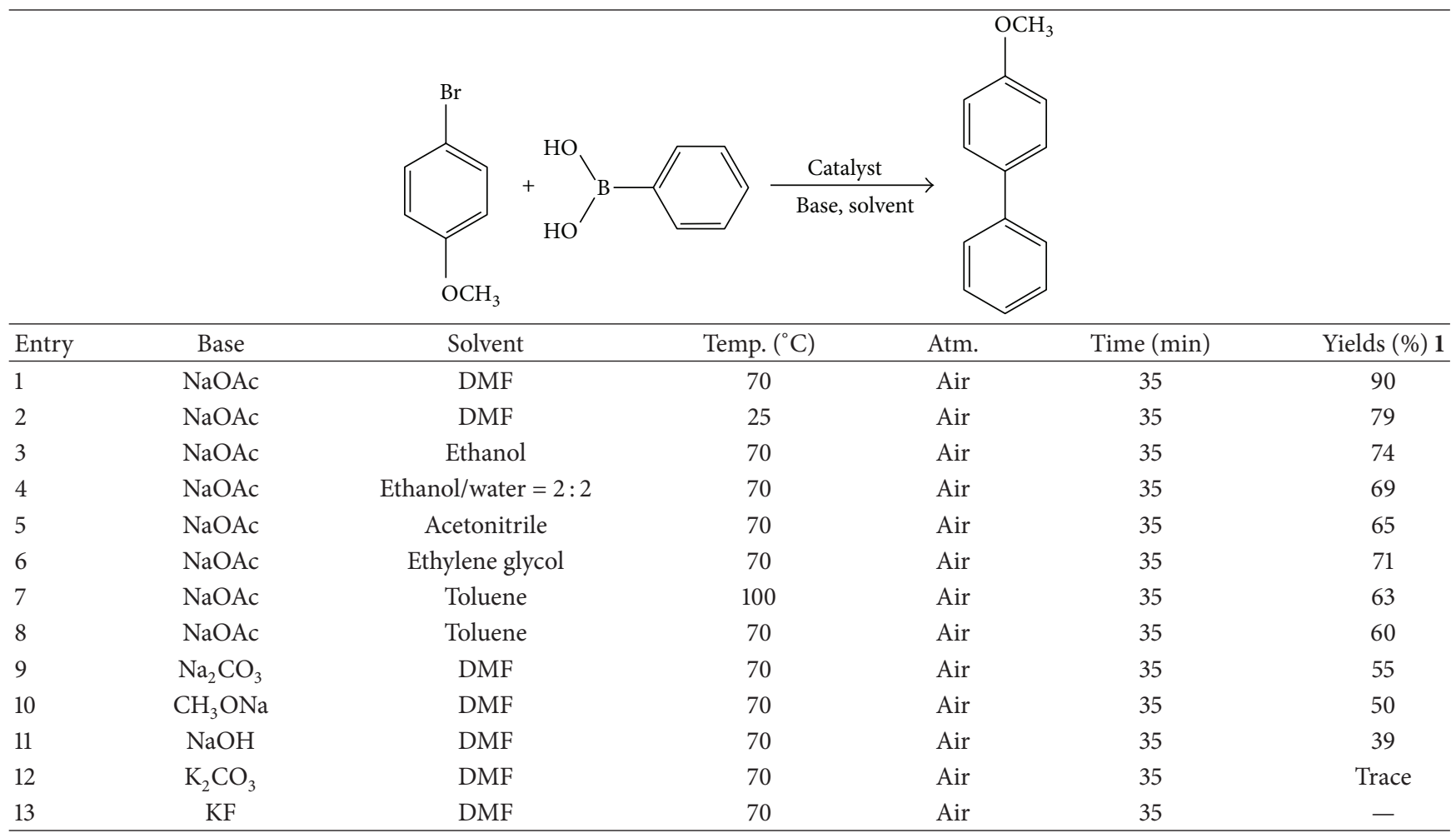

\section{Acknowledgment}

This work was supported by the Natural Science Foundation of the Jiangsu Higher Education Institutions of China (13KJD430003) and Project of Nanjing Science and Technology Development Planning Guidance (2012ZD002).

\section{References}

[1] S. Kumar, M. S. Niranjan, K. C. Chaluvaraju, C. M. Jamakhandi, and D. J. Kadadevar, "Synthesis and antimicrobial study of some Schiff bases of sulfonamides," Journal of Current Pharmaceutical Research, vol. 1, no. 1, pp. 39-42, 2010.

[2] H. F. Guo, X. Zhao, D. Y. Ma, A. P. Xie, and W. B. Shen, "Two palladium(II) complexes based on Schiff base ligands: synthesis, characterization, luminescence, and catalytic activity," Transition Metal Chemistry, vol. 38, no. 3, pp. 299-305, 2013.

[3] K. S. Abou-Melha, "Octahedral Co(II) and Ni(II) complexes of schiff bases, semicarbazone and thiosemicarbazone, synthesis, biological, spectral, and thermal studies," Journal of Coordination Chemistry, vol. 61, no. 13, pp. 2053-2067, 2008.

[4] H. Zhang, D. W. Norman, T. M. Wentzell et al., "Palladium salicylaldimine complexes containing boronate esters," Transition Metal Chemistry, vol. 30, no. 1, pp. 63-68, 2005.

[5] D. Y. Ma, L. X. Zhang, X. Y. Rao, T. L. Wu, D. H. Li, and X. Q. $\mathrm{Xie}$ " "Synthesis, characterization, luminescence, antibacterial, and catalytic activities of a palladium(II) complex involving a Schiff base," Journal of Coordination Chemistry, vol. 66, no. 9, pp. 1486-1496, 2013.

[6] M. Manjunatha, V. H. Naik, A. D. Kulkarni, and S. A. Patil, "DNA cleavage, antimicrobial, antiinflammatory anthelmintic activities, and spectroscopic studies of $\mathrm{Co}(\mathrm{II}), \mathrm{Ni}(\mathrm{II})$, and $\mathrm{Cu}(\mathrm{II})$ complexes of biologically potential coumarin Schiff bases," Journal of Coordination Chemistry, vol. 64, no. 24, pp. 42644275, 2011.

[7] K. H. Wong, M. C. W. Chan, and C. M. Che, "Modular cyclometalated platinum(II) complexes as luminescent molecular sensors for $\mathrm{pH}$ and hydrophobic binding regions," Chemistry, vol. 5, no. 10, pp. 2845-2849, 1999.

[8] F. Neve, A. Crispini, C. Di Pietro, and S. Campagna, "Lightemitting cyclopalladated complexes of 6-phenyl-2,2' -bipyridines with Hydrogen-bonding functionality," Organometallics, vol. 21, no. 17, pp. 3511-3518, 2002.

[9] B. C. Tzeng, S. C. Chan, M. C. W. Chan, C. M. Che, K. K. Cheung, and S. M. Peng, "Palladium(II) and platinum(II) analogues of luminescent diimine triangulo complexes supported by triply bridging sulfide ligands: structural and spectroscopic comparisons," Inorganic Chemistry, vol. 40, no. 26, pp. 66996704, 2001.

[10] N. Miyaura and A. Suzuki, "Palladium-catalyzed cross-coupling reactions of organoboron compounds," Chemical Reviews, vol. 95, no. 7, pp. 2457-2483, 1995.

[11] A. Suzuki, "Recent advances in the cross-coupling reactions of organoboron derivatives with organic electrophiles, 1995-1998," Journal of Organometallic Chemistry, vol. 576, no. 1-2, pp. 147$168,1999$.

[12] H. Naeimi and M. Moradian, "Synthesis and characterization of nitro-Schiff bases derived from 5-nitro-salicylaldehyde and various diamines and their complexes of Co(II)," Journal of Coordination Chemistry, vol. 63, no. 1, pp. 156-162, 2010.

[13] P. Wang, Z. Hong, Z. Xie et al., "A bis-salicylaldiminato Schiff base and its zinc complex as new highly fluorescent red dopants for high performance organic electroluminescence devices," Chemical Communications, vol. 9, no. 14, pp. 1664-1665, 2003. 
[14] H. Fukuda, K. Amimoto, H. Koyama, and T. Kawato, "Crystalline photochromism of N-salicylidene-2,6-dialkylanilines: advantage of 2,6-dialkyl substituents of aniline for preparation of photochromic Schiff base crystals," Organic \& Biomolecular Chemistry, vol. 1, no. 9, pp. 1578-1583, 2003.

[15] Bruker, "APEXII software," Version 6.3.1, Bruker AXS Inc, Madison, Wis, USA, 2004.

[16] G. M. Sheldrick, "A short history of SHELX," Acta Crystallographica A, vol. 64, no. 1, pp. 112-122, 2007.

[17] L. Zhu, R. Bakhtiar, and N. M. Kostić, "Transition-metal complexes as alternatives to proteolytic enzymes. regioselective cleavage of myoglobin by palladium(II) aqua complexes," Journal of Biological Inorganic Chemistry, vol. 3, no. 4, pp. 383-391, 1998.

[18] C. K. J. Jørgensen, “The nephelauxetic series," in Progress in Inorganic Chemistry, vol. 4, pp. 73-124, John Wiley \& Sons, New York, NY, USA, 1962.

[19] S. W. Lai, T. C. Cheung, M. C. W. Chan, K. K. Cheung, S. M. Peng, and C. M. Che, "Luminescent mononuclear and binuclear cyclometalated palladium(II) complexes of 6-Phenyl-2,2' bipyridines: spectroscopic and structural comparisons with platinum(II) analogues1,2," Inorganic Chemistry, vol. 39, no. 2, pp. 255-262, 2000.

[20] N. J. Xiang, T. H. Lee, L. M. Leung, S. K. So, J. X. Shi, and M. L. Gong, "Preparation and photoluminescence of a novel bipolar small organic molecular compound and its $\mathrm{Al}^{3+}$ complex," Chemical Journal of Chinese Universities, vol. 27, no. 5, pp. 808811, 2006.

[21] M. D. Allendorf, C. A. Bauer, R. K. Bhakta, and R. J. T. Houk, "Luminescent metal-organic frameworks," Chemical Society Reviews, vol. 38, no. 5, pp. 1330-1352, 2009.

[22] O. E. Offiong, E. Nfor, A. A. Ayi, and S. Martelli, "Synthesis, spectral and cytotoxicity studies of palladium(II) and platinum(II) amino acid Schiff base complexes," Transition Metal Chemistry, vol. 25, no. 4, pp. 369-373, 2000.

[23] Q. Su, Q. L. Wu, G. H. Li, X. M. Liu, and Y. Mu, "Bissalicylaldiminato zinc complexes: syntheses, characterization and luminescent properties," Polyhedron, vol. 26, no. 17, pp. 5053-5060, 2007.

[24] N. I. Nijegorodov and W. S. Downey, “The influence of planarity and rigidity on the absorption and fluorescence parameters and intersystem crossing rate constant in aromatic molecules," Journal of Physical Chemistry, vol. 98, no. 22, pp. 5639-5643, 1994.

[25] S. M. Islam, P. Mondal, K. Tuhina, A. S. Roy, S. Mondal, and D. Hossain, "A reusable polymer-anchored palladium(II) schiff base complex catalyst for the suzuki cross-coupling, heck and cyanation reactions," Journal of Inorganic and Organometallic Polymers and Materials, vol. 20, no. 2, pp. 264-277, 2010. 

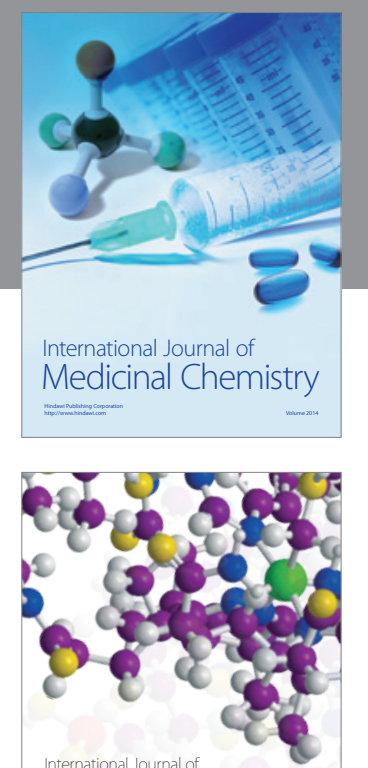

\section{Carbohydrate} Chemistry

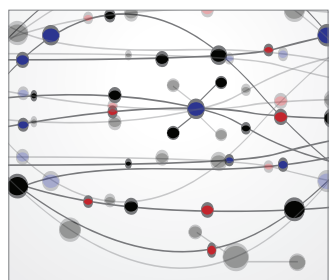

The Scientific World Journal
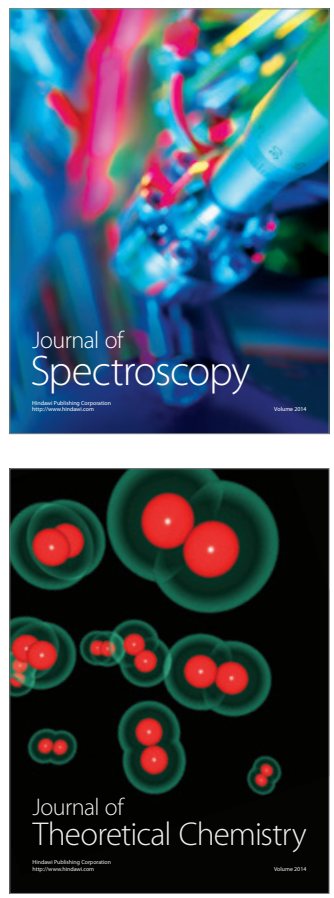
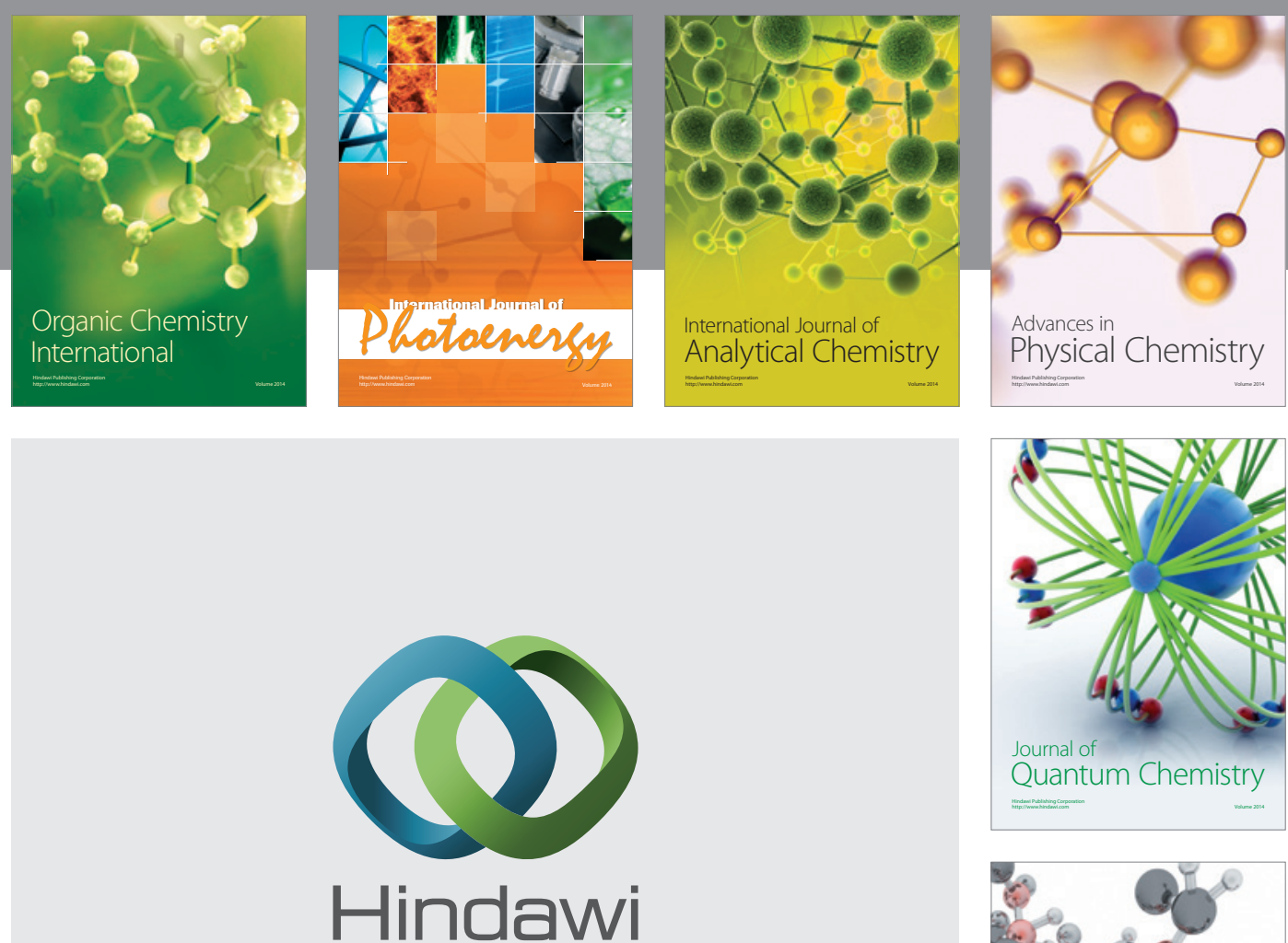

Submit your manuscripts at

http://www.hindawi.com

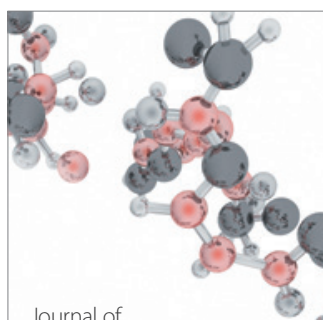

Analytical Methods

in Chemistry

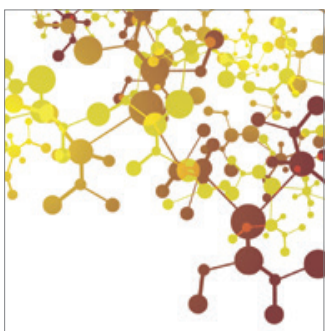

Journal of

Applied Chemistry

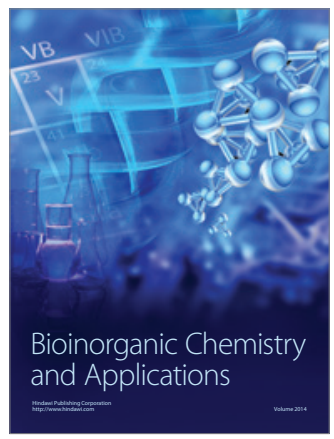

Inorganic Chemistry
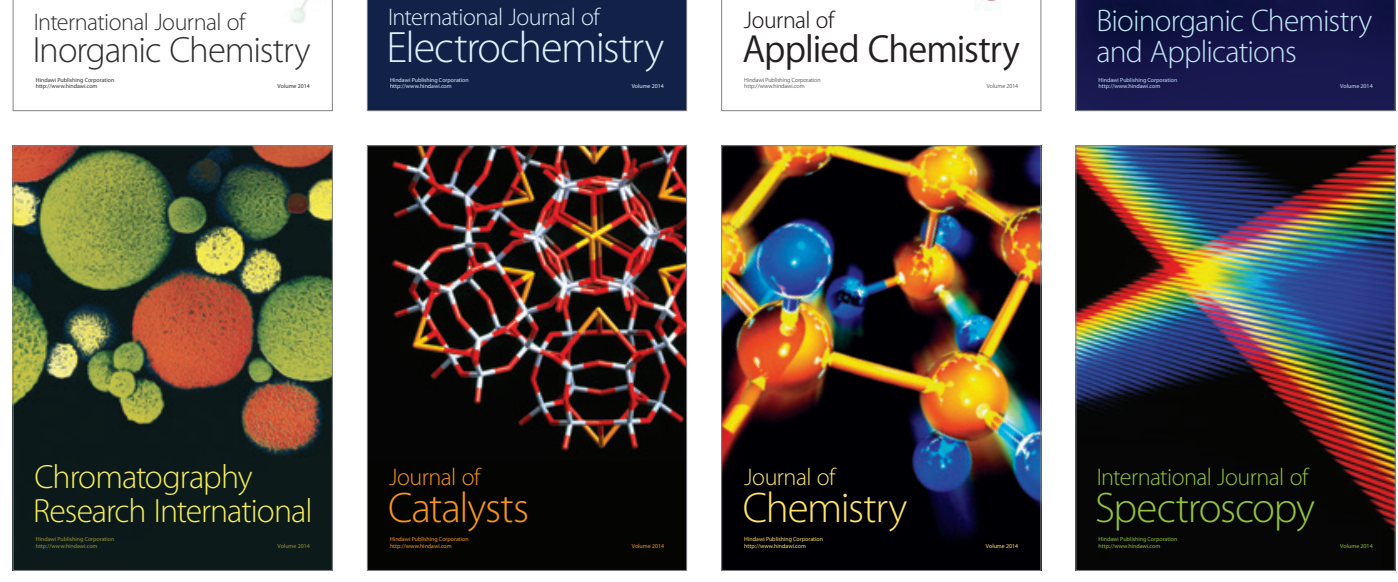